\title{
PUBLISHER CORRECTION OPEN \\ Publisher Correction: Downwind footprint of an urban heat island on air and lake temperatures
}

Ann Cosgrove ${ }^{1}$ and Max Berkelhammer (D) $^{1}$

npj Climate and Atmospheric Science (2019)2:; https://doi.org/10.1038/s41612-019-0064-x

Correction to: npj Climate and Atmospheric Science https://doi.org/ 10.1038/s41612-018-0055-3, Published online 20 December 2018

In the original published version of this Article, revisions that had been requested by the authors at proof correction were not included. Figures 2 and 5 have been resupplied at higher resolution, and the axes and labels on Figs 3 and 4 have been amended for clarity ( $x$-axis labels made uniform between panels in Fig. 4) or added when missing (missing temperature label in Fig. 3a). These corrections have been made to the PDF and HTML version of the article.

\begin{abstract}
(c) (i) Open Access This article is licensed under a Creative Commons Attribution 4.0 International License, which permits use, sharing, adaptation, distribution and reproduction in any medium or format, as long as you give appropriate credit to the original author(s) and the source, provide a link to the Creative Commons license, and indicate if changes were made. The images or other third party material in this article are included in the article's Creative Commons license, unless indicated otherwise in a credit line to the material. If material is not included in the article's Creative Commons license and your intended use is not permitted by statutory regulation or exceeds the permitted use, you will need to obtain permission directly from the copyright holder. To view a copy of this license, visit http://creativecommons. org/licenses/by/4.0/.
\end{abstract}

(c) The Author(s) 2019

'Department of Earth and Environmental Sciences, University of Illinois at Chicago, Chicago, USA

Correspondence: Ann Cosgrove (ann.t.cosgrove@gmail.com) or Max Berkelhammer (berkelha@uic.edu)

Published online: 21 February 2019 